\title{
Research on the competency model of tour guides and the paths of improvement
}

\author{
Cong-Man Wang ${ }^{1, a}$, Dong Ding ${ }^{2, b}$ \\ ${ }^{1}$ College of Economics and Management, Hebei University of Science and Technology, \\ Shijiazhuang 050018, China \\ ${ }^{2}$ College of Economics and Management, Hebei University of Science and Technology, \\ Shijiazhuang 050018, China \\ a50005377@qq.com, ${ }^{b} 197412344 @ q q . c o m$
}

Keywords: Tour guide, Competency model, improving path.

\begin{abstract}
Increasing development of tourism has become an important industry in our country. With the professional quality analysis and literature consult, this paper initially establishes the competency of guides model, and investigtes the tourist guide competency, using the AHP to determine the weight of each elements. Finally, the ways to improve the competency of the tour guide are put forward from three aspects of perfect training mechanism, design reasonable incentive, so as to create a good development environment for development.
\end{abstract}

\section{Introduction}

Tourism refers to the modern society, a kind of short-term residents, the particular way of life, with the characteristics of different places, leisure and enjoyment[1]. In recent years, with the rapid development of China's tourism industry, tourism income and other indicators increased year by year, 2013 the total number of trips to reach 3.262 billion passengers, travel rate $243.5 \%$, international tourism income 51.664 billion US dollars, domestic tourism income 2.627612 trillion yuan[2], Tourism has already become an important industry which growing GDP, improving the quality of life, and play a positive role in economic development and employment promotion. By the end of 2013, the national travel agency business income 35 billion 991 million yuan, travel agency employees reached 339993 people, the national tourism institutions has reached 1832[3], the travel agency has become indispensable in tourist behavior.

Travel agents defined by the World Tourism Organization to give are: retail agencies provide information on possible travel, accommodation and related services to the public, including remuneration and conditions of service information. Tour guide is the core of the reception, to organize the implementation of the tourism action, contact the role of tourists and travel agencies. At present, the level of the tour guide is uneven,often with customer complaints occur. According to statistics, in 2013 China's "Guide Management System" has registered a total of 737,720 guides, which 863 guides have irregularities and be penalized, violation rate reached $1.71 \%$, Marking reasons including beatings abuse tourist and shopping stress, induced to participate in pornography, gambling activities, without changes in tourism projects, refuse or evade inspection, secretly lent tour card, secretly with the group tour, absence group activities without reason, do not carry the formal reception plan, smoking or eating when explain, instrumentation dress untidy and other reasons[4]. The same year all levels of National Tourism Quality Supervision and law enforcement agencies to accept 11369 tourist complaints, of which 5123 complaints for the travel agency[5].

At present, the research on the guide more emphasis quality, there is a comprehensive analysis of the psychological quality and cultural quality. The main body of research is the human resources management manager, the senior management of the enterprise, the sales staff, and lack of literature on the competency model of tour guides, on the determination of competency elements to pursue a comprehensive, ignore the relationship between competency and performance. The research method mainly depends on the observation or empirical judgment, and lack of empirical research. Therefore, 
build a suitable guides competency model is played a positive role in their recruitment, training, assessment, and conducive to enhancing the ability of the tour guides, better service for tourists and improve their own.

\section{Model Construct}

\section{Definition of competency elements of tour guides.}

According to China "tour guide staff regulations", and China's current tourism development situation and guide service object, analysis of four aspects of the quality of tour guide thought quality, moral quality, knowledge quality, skill quality, summed up the tour guides should have service awareness, professional ethics, excellent ethics, language knowledge, historical and cultural knowledge, tourism policies and regulations, organizational capabilities, and emergency response ability and other qualities.

Recalling guides competency and related competency model through literature can be summed tour guides competency element further comprising are follow: aesthetic knowledge, psychological knowledge, common sense of travel, love their work, independent study, and interpersonal understanding, confidence, strong willed, tenacity, stable mood, emotion management, sense of community, organization and discipline, spirit of collaboration, teamwork, consciously take the initiative, responsiveness and resilience, rapid, self-control, keen insight, concentrate, cultural etiquette, strong affinity, responsibility, credibility and integrity, be innovation-minded, physical and mental health, achievement motivation, adaptability, flexibility, the ability to deal with conflict, crisis management capabilities, Manner and Appearance, decision-making ability, analysis ability, and ability to establish relations.

By merging similar elements, the competency of the tour guide is divided into three dimensions, to construct the competency index system of tour guides, and including total 25 elements,as shown in table 1.

Table 1 Competency Elements of Tour Guides

\begin{tabular}{|c|c|}
\hline Dimensions & Elements \\
\hline $\begin{array}{c}\text { Personal } \\
\text { qualities }\end{array}$ & $\begin{array}{c}\text { Confidence,Tenacity,Initiative,Responsibility,Spirit of } \\
\text { innovation ,Achievement Orientati,Adaptability, } \\
\text { Manner and Appearance,Health }\end{array}$ \\
\hline $\begin{array}{c}\text { Professional } \\
\text { knowledge }\end{array}$ & $\begin{array}{c}\text { History and cultural knowledge,Tourism policies and } \\
\text { regulations,common sense of tourism,Aesthetic knowledge,Etiquette and } \\
\text { custom,Continuous learning }\end{array}$ \\
\hline $\begin{array}{c}\text { professional } \\
\text { skills }\end{array}$ & $\begin{array}{c}\text { Emotional Management,Interpersonal comprehension } \\
\text { ability,Communication ability,Sense of community,Teamwork,Service } \\
\text { awareness, } \\
\text { Credibility and integrity,Professional }\end{array}$ \\
& ethics,Abilities of induction and deduction,Ability of handling crisis \\
\hline
\end{tabular}

\section{The establishment of competency model of tour guide.}

According to the tour guide competency elements analysis, the questionnaire has designed, the questionnaire uses the Likert scale, "1" to "5" represent " Very unimportant " and "unimportant" and "general" "important" "very important", from "1" to "5" said coincidence degree increases gradually. Require the respondents to compare themselves in the tour guide during the operation, the control survey of the degree of compliance to make relevant decision. The questionnaire through the network issued a total of 155 , recycling 155 , the recovery rate of $100 \%$, the questionnaires that missed important information and the randomness of strong invalid questionnaires were excluded.143 valid questionnaires were obtained, and the effective rate was $92.26 \%$. The questionnaire on average competency index important degree score were more than 3 points, so there is no less important elements. The results using the method of AHP, construct four judgment matrix, four matrices were tested with consistency $(\mathrm{p}<0.05)$,then get weight and ranking of three dimensions, 25 elements, the calculation process has been omitted.And the results are shown in table 2 . 
Table 2 Weight and Ranking of Each Elements

\begin{tabular}{|c|c|c|c|c|}
\hline Dimensions & Elements & Weight & Total weight & ranking \\
\hline \multirow{9}{*}{ Personal qualities } & Confidence & 0.1103 & 0.01804 & 17 \\
\hline & Tenacity & 0.0589 & 0.00964 & 20 \\
\hline & Initiative & 0.1621 & 0.0265 & 14 \\
\hline & Responsibility & 0.3004 & 0.04909 & 8 \\
\hline & Spirit of innovation & 0.0234 & 0.00383 & 24 \\
\hline & Achievement orientati & 0.0197 & 0.00323 & 25 \\
\hline & Adaptability & 0.0563 & 0.00921 & 21 \\
\hline & Manner and appearance & 0.0471 & 0.00770 & 22 \\
\hline & Health & 0.2212 & 0.03616 & 12 \\
\hline \multirow{6}{*}{ Professional knowledge } & History and cultural knowledge & 0.2325 & 0.06905 & 4 \\
\hline & Tourism policies and regulations & 0.1279 & 0.03800 & 10 \\
\hline & common sense of tourism & 0.3597 & 0.10684 & 3 \\
\hline & Aesthetic knowledge & 0.0247 & 0.00734 & 23 \\
\hline & Etiquette and custom & 0.1725 & 0.05123 & 7 \\
\hline & Continuous learning & 0.0824 & 0.02448 & 15 \\
\hline \multirow{10}{*}{ professional skills } & Emotional Management & 0.0423 & 0.02283 & 16 \\
\hline & Interpersonal comprehension ability & 0.0702 & 0.03789 & 11 \\
\hline & Communication ability & 0.1022 & 0.05515 & 6 \\
\hline & Sense of community & 0.0330 & 0.01781 & 18 \\
\hline & Teamwork & 0.0535 & 0.02890 & 13 \\
\hline & Service awareness & 0.0864 & 0.04665 & 9 \\
\hline & Credibility and integrity & 0.2173 & 0.11728 & 2 \\
\hline & Professional ethics & 0.2569 & 0.13866 & 1 \\
\hline & Abilities of induction and deduction & 0.0204 & 0.01102 & 19 \\
\hline & Ability of handling crisis & 0.1174 & 0.06336 & 5 \\
\hline
\end{tabular}

The competency model of tour guides is constructed as the following figure 1 : 


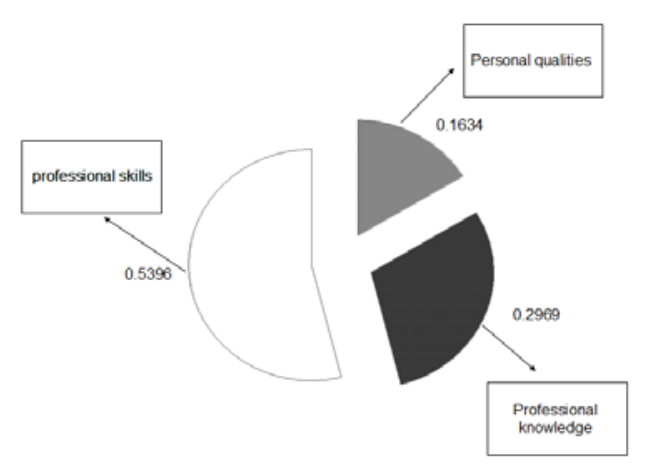

Fig.1 Competency model of tour guide

\section{Conclusion}

The weight of common sense of tourism and history and cultural knowledge accounted for $58 \%$ in the dimension of professional knowledge. It can be seen that visitors has a urgent needs to the enhance of tour guides' common sense of tourism and history and cultural knowledge, and also expect the tour guide to have the appropriate etiquette, understand and respect the folk.

The dimensions of professional skills in the competency model of the weight up to 53\%, professional ethics, credibility and integrity,ability of handling crisis and communication ability accounted for $67 \%$,.As the tourism products richer and richer, visitors to the tour guide is not just the traditional explanation and organization, they pay more attention to whether the tour guide has a good moral quality, whether to establish mutual trust and friendly interpersonal relationship in a short time. Tourism process requires multi cooperation, coordination of various organizations, it's in a constantly changing environment, tour guides must have the ability to deal with the crisis, so that it can cope with the unexpected situation, and ensure the smooth progress of the trip.

The market is in constant change, so the tour guide must improve themselves to meet market demand by continuous learning. Organized and planned training is the most important way to improve the competency of the tour guides. Based on the competency model, travel agency can build leaning organization,and conduct basic knowledge and basic skills training regularly to tour guide, to improve the guide's cultural literacy and working ability. Guide themselves should also pay attention to continuous learning, consciously take the initiative to update knowledge, perfecting their knowledge system, cultivation of conscious sense of responsibility, sense of service and team spirit etc. personal accomplishment and exercise treatment crisis, interpersonal communication and emotion management ability, Conscious cultivation sense of responsibility, service consciousness and team consciousness, and training the ability to deal with crisis, interpersonal communication and emotion management.

Due to the tourism industry in our country is still in primary stage of the sightseeing tourism, enable senior tour guide demand is not obvious, which leads to the primary guides has no motive power to upgrade themself, resulting in high-quality talents drain, low level of tour guides is full of tourism human resources market, tourism industry has formed a typical Gresham's phenomenon.

According to the competency model of tour guides, the regulatory authorities can assess their knowledge and ability, and determine the compensation according to their comprehensive quality, encourage the tour guides to participate in the competition and improve their comprehensive ability from two aspects of material and spirit. At the same time, improve the exit mechanism, adopts the standard annual examination system, perfect channels for complaints and other measures, remove the tour guides who is not qualified for the work timely from the market of tour guides. Reasonable incentive and punishment can curb the Gresham's law, effectively enhance the competency of tour guide groups.

Partial tour guide value concept of honor and disgrace deviation, lead to the lack of trust between tourists and tour guides, it is difficult to establish mutual understanding and mutual trust of interpersonal relationships. Bureau of tourism and travel agency can help tour guides to establish the 
moral outlook and concept of honor and disgrace concept with a sense of responsibility and the sense of belonging via the guidance of public opinion, so that consciously abide by the occupation moral reconstruction, the trust between organizations, take the initiative to improve the service quality and business level. With the establishment of a good development environment, a healthy development of the tourist guide industry can be promoted.

\section{References}

[1] Guangyuan $\mathrm{Yu}$, To master the basic characteristics of tourism and the basic task of the tourism industry,J. Travel times, 1986.

[2] Meilan Jin, The quality of tour guide under the competency model,J. China Journal of Commerce.(2012)166-167.

[3] Xili Luo, Research on the performance appraisal profession Index System of Tour Guides based competency model,J. Chinese \& Foreign Entrepreneurs.(2015)138, 140.

[4] Ran Li, Research on the psychological quality of tour guide,J. Journal of Taian Institute of Education.(2004) 40-41.

[5] Qunzhen Qu, and Ping Wang, Research on the construction and application of the competency model of tourism talents in China,J. Jiangsu Commercial Forum.(2011)104-106. 